\title{
Environmental tools of atmospheric protection in the Czech Republic
}

\author{
O. Malíková \& M. Černíková \\ Faculty of Economics, Technical University of Liberec, Czech Republic
}

\begin{abstract}
The Czech's relationship to the environment and its protection has undergone a relatively long development. In the late $20^{\text {th }}$ century the Czech Republic changed the political system as well as its environmental behaviour. At the beginning of this period the Czech Republic was one of the most polluted regions of Europe. With the change of a political situation in 1989, problematic status of the air pollution in the Czech Republic has been significantly improved. Current status and positive progress of the environment in the context of a sustainable development is guaranteed by the EU legislation also in the Czech Republic.

The aim of this paper is to discuss the status of atmospheric protection and its efficient tools used in the Czech Republic. In accordance with the sustainable development requirements, advanced countries establish systems of environmental tools affecting interaction between manufacturing corporations and the major components of the environment, especially air. The paper describes the system of atmospheric protection in the Czech Republic and administrative tools which are quite efficient and well applicable in a corporate environment. The tools however bring plenty of problems as well. The paper analyzes increased attention to economic tools, especially the potential of a tax system. Another issue that is recently discussed quite frequently is the so-called ecological tax reform which could also be used as another important environmental tool. A new dimension of the environmental regulation of atmospheric protection is represented by voluntary activities of the companies. For a successful combination of atmospheric environmental protection instruments in the Czech Republic it is necessary to assess their economic efficiency and environmental performance. The Czech Republic has proved the system for effective atmospheric protection which brings significant results. Despite the improvements, there are still developed and implemented new tools for atmospheric protection.
\end{abstract}

Keywords: atmospheric protection, environmental tools, administrative tools, 
economic tools, tax reform, voluntary activities by companies, economic efficiency, environmental performance.

\section{Introduction}

The contemporary activity of economic entities is always more or less adherent to the deterioration of all components of the environment, mainly air quality. The extent of not only local and regional, but also national and international negative impact on the environment demonstrates that we simply cannot rely on market mechanisms, hoping they will regulate such an impact on the environment automatically. The deficit in the functioning of market mechanisms is caused by a collective ownership of environmental goods that are globally used by the whole community [1]. In context of requirements on a sustainable development of a civilized community it is necessary to systematically control and manage interactions between the economic development and the state of the environment.

In the activities of economic entities, especially in the developed industrial areas, the market balance has been impaired due to various reasons which lead to the occurrence of negative externalities relating to air pollution. The conflict between the interests of the polluter and concerns of the company results in a necessity for the management of the conflict using various environmental tools of atmospheric protection. This article presents relevant groups of environmental tools implemented in the Czech Republic environment and examines approaches to the evaluation of the success relating to the implementation of this atmospheric protection regulation.

\section{Atmospheric quality protection in the Czech Republic}

The relationship with the environment has been developing over a relatively long period in the Czech Republic. At the end of the 80's the Czech Republic was facing not only problems related to the change of a political system, but also a big devastation of the environment as a result of a complete absence of an ecological policy and other aspects in a socialist government decision-making. For many decades the main priority of 'building the system of socialism' remained a quantitative growth of mainly primary sector and heavy industry without any respect to the environmental protection requirements; due to this attitude the Czech Republic was one of the most polluted regions in Europe with the highest emission of a wide range of pollutants in the air. The change of a political system in 1990 brought about a significant improvement of air quality in the Czech Republic. Figure 1 shows the development of air pollution by major pollutants in the Czech Republic within the past twenty years [2].

The main reasons for a more satisfactory air condition in the Czech Republic were mainly the decrease of industrial activities in the first few years after November 1989, enforcing key laws related to the environmental protection, founding relevant environmental institutions and creating an effective system of 


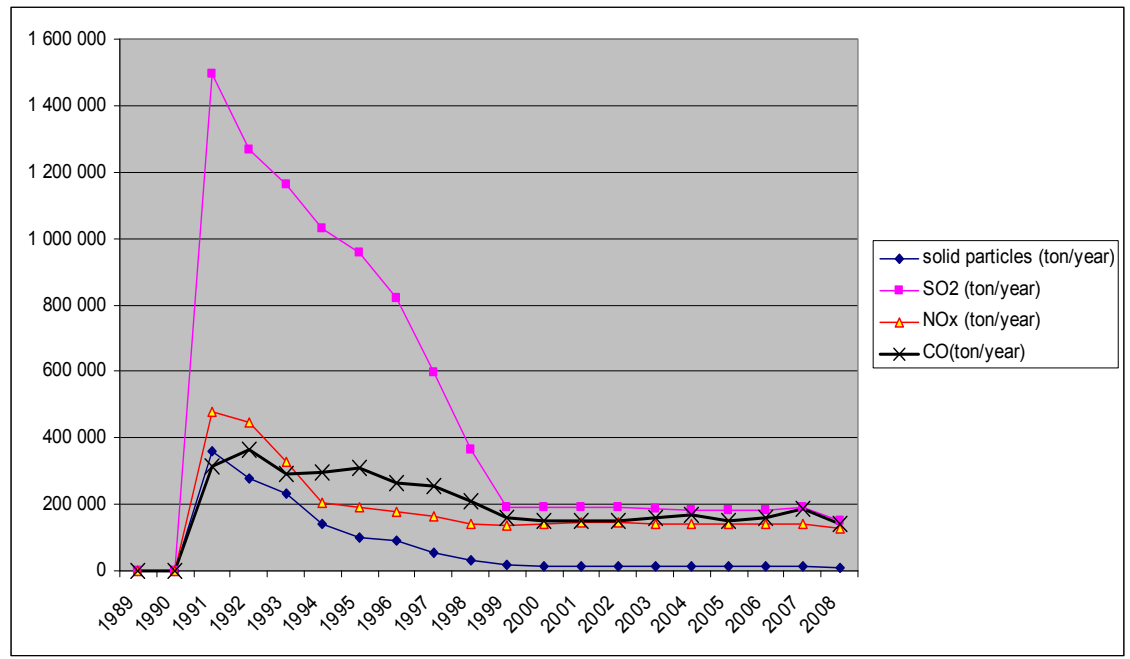

Source: author's submission, the Czech statistical Office [3].

Figure 1: Development of air pollution by major pollutants in the Czech Republic.

environmental protection. The sulphur oxide air pollution was significantly reduced. Companies emitting these pollutants to the air were forced to take measures in a relatively short time to meet strict limits, which in some cases lead to cuts in production or even its closing. Other pollutants that did not reach such high levels are still present in the air and their reduction is problematic for many reasons not only in the Czech Republic, but also in Europe - the situation of air pollution has been steady for the last few years. A number of measures have been taken leading to a higher atmospheric protection since the Czech Republic joined the EU. A present state and a satisfactory development of atmospheric protection in the Czech Republic is guaranteed by the need to conform to the European Union legislation.

\section{Environmental tools of atmospheric protection}

In the past few decades multiple environmental tools were implemented in the Czech Republic with various levels of effectiveness in relation to the air quality. These tools may be divided into several groups.

\subsection{Normative (administrative) tools}

Normative tools of the environmental policy are based on the compulsory authority of state administration bodies. Such tools especially cover:

- directives (orders and prohibitions),

- limits (material, time),

- rules and technical standards. 
Regulation system of atmospheric protection is based on the legislatively supported administrative measures intended to affect the behavior of polluters, their control and imposition of possible sanctions (fines, penalties) in case of non-performance of the legislative requirements. These tools are environmentally effective, however they are accompanied with quite a lot deficiencies [4]. Direct regulation requires extensive administration and subsequent inspection. This means a risk of inefficient bureaucratic management, corruption and needless expenses. Despite many disadvantages and difficulties, normative tools have been so far the most expanded and the most widely used tools in the field of atmospheric protection. Direct regulation is especially effective in the areas where the goals must be achieved immediately. The current requirements for environmental maturity of economic subjects however require new attitudes that offer multiple options and promote voluntary approaches.

\subsection{Economic tools}

Economic tools of atmospheric protection are based on the indirect affecting the behavior of economic subjects causing harm to the environment [5]. Each economic subject (companies, households) may decide whether it is more advantageous to expend some money on mitigation or elimination of impacts on the environment or to damage the environment and pay for it in the form of fees and taxes. New environmental protection system that has been developing in the Czech Republic since 1990 makes use of various economic tools for the environmental protection. Amongst the most significant economic tools we count for instance the fees for atmospheric protection; in the recent years this issue is also more increasingly considered in the governmental tax system.

\subsubsection{Fees designated for the atmospheric protection}

The most widespread form of economic tools of atmospheric protection in the Czech Republic are the tools of so called negative stimulation, especially the fees designated for the atmospheric protection. The amount of such fees usually depends on the quantity and concentration of the emissions released to the air. The fees are considered as environmental costs of companies - polluters. The fee should motivate the companies - polluters to adopt such measures that will contribute to atmospheric protection. The amount of the fee should be based on the costs for the elimination of damage, so that no economic advantage is given to those organizations that pay lower amount than the potential environmental damage. The fee should be also a tool for giving a priority in the market to those companies that act responsibly and protect the atmosphere. Their market position should be then stronger [6].

\subsubsection{The Czech Republic tax system}

Another economic tool that is contributing to atmospheric protection is the Czech Republic tax system, with many more standard functions (allocation, distribution, fiscal). In this way the functions of the tax system are extended thus the tax system not only acts as a fiscal tool that brings certain tax revenues 
into public budgets, but also a tool of the state environmental policy aimed at the limitation of air quality deterioration [7].

As for the current tax legislation of the Czech Republic, environmental aspects are incorporated in the direct taxes section in form of multiple tax allowances, disallowances or exemptions facilitating the environmental protection process [8]. The crux of the environmental regulation is currently moving mainly to the area of indirect taxes. Indirect taxes have imminent effect on the price of the goods they are imposed on - thus they can greener production with lower emissions.

The move to indirect taxes should be - in accordance with the principle of tax neutrality - compensated by reduction of other taxes. In the end this should contribute to the growth of national economy. Reduction of labor costs should help to maintain competitiveness of our economy. At the same time it should represent a kind of stimulus attracting foreign investors. In the EU countries this conception (so called ecological tax reform) has been discussed for many years as one of the potential approaches to improvement of the quality of environment and also to lowering air emissions.

Ecological tax reform should be implemented in the Czech Republic in three successive phases in the period 2007-2017. Just as in other EU countries also in the Czech Republic the reform should be based on the principle of tax neutrality, i.e. revenues should be used for the reduction of labor costs.

The first phase of the ecological tax reform was completed by introduction of the Council Directive 2003/96/EC into the Czech Republic legislation. Since 2008 the existing tax system of the Czech Republic was amended by taxation of energy products and electricity through the Act No. 261/2007 Coll. The subject of taxation covers natural gas, solid fuels and electricity [9]. Reduction of labor costs in 2008 was realized by abatement of income tax of both physical and legal entities. Quite extensive amendment to the income tax legislation changed the system for determination of tax base and tax allowances and also lowered the social insurance rates.

The second phase of the ecological tax reform should be realized in the period 2010-2013. During this phase tax rates and allowances for solid fuels and natural gas should be changed. The main goal is to revise the existing fees and other tools with an option to transform the selected environmental fees to environmental taxes. Special attention should be paid to traffic, as one of the main air polluters, but also to administration of environmental taxes or transformed fees, especially to the principle of tax neutrality.

The third phase is scheduled to the period of 2014-2017. In general this phase should correspond with the amended EU directives. Its conception should be based on the analysis of the two previous phases, assessment of all their effects and impacts and probably it will also be based on the political situation in the Czech Republic in the forthcoming decade [10].

So far the economic tools do not represent the core area of atmospheric protection in the Czech Republic. In practice there is still a significant majority of normative tools, while economic tools are rather perceived as a certain supplement to the normative ones. At creation of specific atmospheric protection 
policies, both groups of tools are not considered as equal. The main reason for the existence of economic tools is mainly their fiscal effect [11].

\subsection{Voluntary environmental activities by organizations}

With the requirement for a sustainable development and the constantly increasing environmental awareness new voluntary approaches to atmospheric protection have been emerging since the eighties of the last century. Voluntary activities support the strategy of preventive approaches realized by companies beyond the scope of the statutory legislation framework with the aim to mitigate negative impacts of their activities on the environment, to consolidate their market position, to improve their competitiveness as well as the company image [12]. This is a significant turnover in the perception of atmospheric protection. Small effect of sanctions or various subsequent recourses leads to a deflection from these traditional tools and inclination to voluntary preventive actions that are introduced into decision-making processes at the company level, affecting each and every activity of the company that is related to the environment. Voluntary activities are consolidated at the international level and the wide range of tools implemented also by business entities in the Czech Republic [13]. Voluntary environmental activities of companies may be considered as voluntary tools and recommended approaches.

Implementation of voluntary tools into company practice is a good opportunity, however there may be some risks and doubts that will probably appear and will be solved in near future. Should the voluntary activities be a fullfledged instrument for the meeting of atmospheric protection goals of companies, the companies must be mature and responsible enough to be able to deal with the environmental protection individually, but at the same time in accordance with the goals and directions of the governmental policy. This is one of the reasons why we must state that in Czech Republic the process of implementation of voluntary activities stands at the beginning of a relatively long way.

\section{Effectiveness of atmospheric protection tools}

To achieve the set environmental goals, we can use a wide range of tools combining especially the normative and economic tools, but also some voluntary approaches of companies. Each of these tools has its positives, but the implementation always brings some negatives as well. While preparing its own atmospheric protection conception the government decides about the effective and suitable combination of all the tools in order to achieve the selected environmental goals [14]. Should this selection be rational, certain criteria must be considered in order to choose suitable tools in context with the goals set (see Fig. 2. 


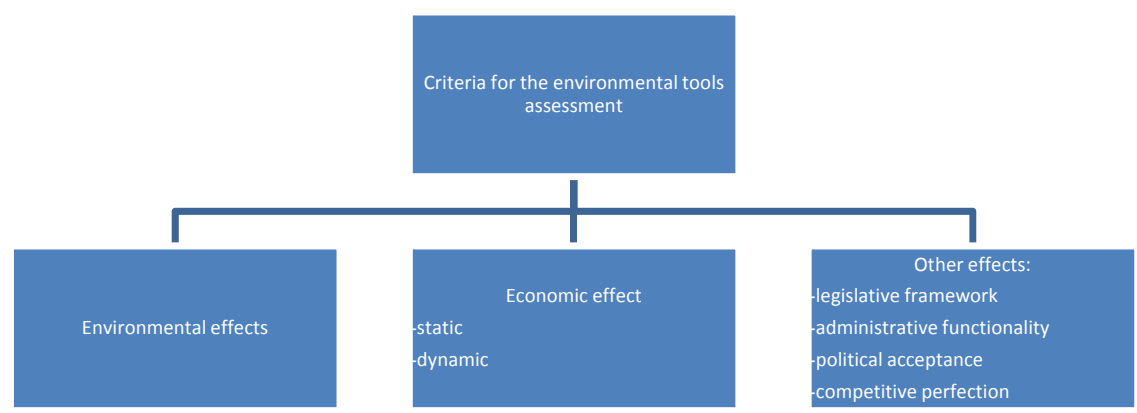

Source: author's submission

Figure 2: Potential criteria for the atmospheric protection tools assessment.

Environmental effects - the tools must demonstrably fulfill the requirements that were set in the field of atmospheric protection.

Economic effect - implementation of the tools should be connected with minimum community costs (administrative, legislative, inspection, etc), but incentives for the elimination of environmental deterioration should be clear and obvious - so called static effect. At the same time there should be some space left for innovations of companies in this field (implementation of more environmentally friendly technologies, green products) - this may give a strong boost to the economic effect of the environmental tools (dynamic effect) [15].

Legislative framework - all activities connected with the implementation of environmental tools cannot be realized within a single insulated legislative framework - national legislation must be interconnected with EU legislation and environmental protection issues must be dealt with in a complex way.

Administrative functionality - there is a requirement for simple implementation and administration of environmental tools. Good knowledge of the tools is a necessary presumption for proper administration.

Political acceptance - in a broad sense this refers to a general feasibility of the environmental tools. In the strict sense of the word particular environmental tools must be accepted by various groups concerned (political groups, state administration, companies, private parties concerned, etc) for their successful implementation. A necessary precondition is their political transparency and comprehensibility.

Competitive perfection - the tools must not create any competitive barriers or limits that would be in conflict with the applicable international legislation (especially the European regulations and directives on restrictive trade practices). The tools should not prevent new entities from entering the national (or international) market or tend to creation of monopolies [16].

In order to achieve the set goals in atmospheric protection area, it is necessary to make use of a suitable combination of the available tools. Should the selection be rational, certain criteria must be considered in terms of suitability of particular 
tools. Besides environmental effects we must also analyze economic effect and other aspects of each environmental tool to be implemented.

\section{Conclusion}

Companies should assume responsibility for contamination and deterioration of the air caused by their activities and should include these negative externalities into their costs. Internalization of externalities is especially possible through tools that are implemented by government and relevant authorities through the national environmental policy. Normative tools are relatively used with more frequency, while economic environmental tools bear quite a big potential. There is however also a real risk that the primary environmental effect of these tools will be reduced by other secondary effects that are also expected from the economic tools. This is also supported by the fact that the main motivation of government, while implementing economic tools, is their fiscal effect. Low efficiency of economic tools reflects inadequate evaluation of economical aspects of environmental protection. Also the interconnection between environmental goals and tax legislation is not optimal as the current tax incentives are rather indistinctive and not much motivating for the companies. The conception of the ecological tax reform - with its main idea "from taxation of labor to taxation of environmentally unfriendly products and services" - is quite interesting and the European countries adopt it as a potential tool for the satisfaction of the sustainable development goals in a long-term horizon. Implementation of reform conceptions however always bring some risks, for instance it is not possible to get some accurate estimation of revenues from this reform, the direction to internalization of negative externalities is not obvious and also the basic attribute of the reform - tax neutrality is, as far as I think, rather controversial. Companies should set a new dimension in their interaction with the environment and through a wide selection of voluntary activities control, evaluate and guide their environmental behavior.

\section{Acknowledgements}

This article was worked up as one of the outputs of the research project "Environmental Tax Reform in the Context of Environmental Policy of the Czech Republic", which was implemented at the Faculty of Economics of Technical University in Liberec in 2011 with the financial support from the Technical University in the competition supporting specific projects of academic research (student grant competition).

\section{References}

[1] Villlacampa, Y. \& Brebbia, C.A., (eds). Ecosystems and Sustainable Development VIII, WIT Press: Ashurst, 2011. 
[2] Zprávy o životním prostředí v jednotlivých letech. Ministerstvo životního prostředí, Online. www.mzp.cz

[3] Stav životního prostředí v jednotlivých letech. Český statistický úr̆ad, Online. www.czso.cz/csu/edicniplan.nsf

[4] Wiener, J., Global Environmental Regulation: Instrument Choice in Legal Kontext. Yale Law journal, (108), p. 983, 1999.

[5] Endres, A., Umweltökonomie: Arbeits - und Übungsbuch, Kohlhammer: Stuttgart, pp. 120-150, 2007.

[6] Nástroje environmentální politiky. Centrum pro otázky životního prostředí, Online. www.enviwiki.cz

[7] Ščasný, M., Administrativní a vyvolané náklady poplatků za znečist'ování ovzduší a energetické daně. Proc. Of the $1^{\text {st }}$ Int. Conf. On Modelováni dopadi̊ environmentální regulace, ed. M. Ščasný, COŽP Univerzity Karlovy: Praha, pp. 9-11, 2010.

[8] Bosquet, B. Environmental tax reform: does it work? Ecological Economics, 1(34), pp. 19-32, 2000.

[9] Marková, H. Daňové zákony 2011. Grada Publishing: Praha, pp 215-228, 2011.

[10] Principy a harmonogram ekologické daňové reformy. MŽP ČR, Online. www.mzp.cz

[11] Poterba, J., Tax policy and the Ekonomy, MITT Press: Massachusetts, pp. 150-182, 2006.

[12] Burrit, R. \& Schaltegger, S., An Introduction to Corporate Environmental Management Striving for Sustainability, Greenleaf Publishing: Sheffield, pp. 58-72, 2003.

[13] Remtová, K., Dobrovolné environmentální aktivity. Orientační příručka pro podnikatele Planeta, 6(14), pp 3-27, 2006.

[14] Stehling, F., Ökonomische Instrumente der Umweltpolitik zur Reduzierung stofflicher Emissionen, Universität Ulm: Ulm, pp. 150-170, 1999.

[15] Burrit, R., \& Schaltegger, S., An Introduction to Corporate Environmental Management Striving for Sustainability, Greenleaf Publishing: Sheffield, pp. 85-112, 2003.

[16] Fitzgerald, J., Assessing Vulnerability of Selected Sectors under Environmental Tax Reform: The Issue of Pricing Power. Journal of Environmental Planning and Management, 3(52), pp. 413-533, 2009. 